\title{
Correlations between different methods of vertical jump and static balance parameters in athletes
}

\author{
Mehmet GOKTEPE ${ }^{1}$, Mehmet GUNAY ${ }^{2}$, Sakir BEZCI ${ }^{3}$, Metin BAYRAM ${ }^{4}$, \\ Ali OZKAN ${ }^{1}$
}

${ }^{1}$ Bartın University School of Physical Education and Sport, Batın, Turkey.

${ }^{2}$ Gazi University School of Physical Education and Sport, Ankara, Turkey.

${ }^{3}$ Karabük University School of Physical Education and Sport, Karabük, Turkey.

${ }^{4}$ A ̆̆gr İbrahim Çeçen University School of Physical Education and Sport, A $\breve{g} r$, Turkey.

\begin{abstract}
This study aims at determining the correlations between different methods of vertical jumping and static balance. A total of 46 male athletes (handball players 14, volleyball players 13, and soccer players 19) were included in the research. For each participant, the following measurements were made respectively: 1) height and weight measurement, 2) 5-minute warm up run, 3) trial measurements so that participants could adjust to the balance platform, 4) Static balance measurements, 5) jumping measurements; and then the procedure was ended. The "Descriptive" test was employed for numerical variables, and descriptive statistics were represented as averages \pm standard deviations. Because parametric test assumptions were not met in analysing the independent variables for the participants, Spearman's Moments Multiplication Correlation test was used. In consequence, statistically significant correlations were not found between static jump and counter movement jump - vertical jump methods- and static balance parameters ( $p>0.05)$. Yet, it may be said that statistically significant correlations are available between drop jump and static balance parameters $(p<0.05)$. It was found that there were significant correlations between static balance and drop jump in athletes, but that there were no significant correlations between static jump and counter movement jump.
\end{abstract}

Keywords: Athletes, counter movement jump, drop jump, static balance, static jump, vertical jump.

\section{INTRODUCTION}

Jumping is an organism's pushing the surface of leaning and leaving the ground vertically or horizontally and suspending in the air for a short time. Jumping is dependent on the power of leg muscles, their explosive power, the flexibility of muscles involved in jumping, and on the technique of jumping (13). Jump movement is dependent on the speed of muscle contraction, and the development of muscle strength. On examining jumping movement, it was found that flexor and extensor groups were influential in this $(7,20,26)$. Vertical jumps are the jumps made in a vertical plane. What is essential here is to gain height from the ground. The direction is upward primarily. For instance, jumps over a hurdle or a box $(6,13)$. Even though jumping, sprint and agility are versatile abilities; a small number of publications contain the importance of falling mechanisms, balance and posture (19). In determining the speed modelling; stopping time, body posture was also emphasised in addition to flight time, flight distance, speed of landing, changes in speed, strength used. Therefore, a factor of training in sprint, jump and agility activities may be balance and stability activities (2). Balance is defined as the ability of the centre of the body to remain in maximal stability with minimal slide (12). Balance is controlled by central nervous system, and it is performed with the combination of data coming from vestibular, somatosensory and visual systems. Two type of balance- static and dynamic balance- are mentioned in the literature. Static balance is defined as attaining the balance in a stable position with minimal movement (32). After improvement is made in static balance in athletes, exercise with dynamic balance follows. Such activities include activities specific to sport such as running, lateral movements and backward movements. More developed dynamic activities are jumping, shearing, curling and rotating. They are initially done slowly in balance and under control, and then speed is gradually increased (18). The 
authors pointed out that the ratio of prime mover muscles will be reduced with the development of balance ability to ensure body stabilisation, and thus these muscles will function as the driving power in such activities as jumping and running. As Chaouachi et al. (2) point out, in the absence of optimal balance, sport performance can be negatively influenced in repetitive jumping, sprint and in activities involving agility. For this reason, it is extremely important that jumping and balance performance should be considered together in athletes. However, on reviewing the literature, no studies concerning the correlations between the methods of vertical jumping and balance were found in the literature. In the light of the points made above, this study aims to determine the correlations between different methods of vertical jumping and static balance parameters.

\section{MATERIAL \& METHODS}

A total of 46 male athletes who were playing in the school team of Ağrı Ibrahim Çeçen University, 14 of whom were handball players, 13 of whom were volleyball players, and 19 of whom were soccer players were included in the research. Prior to the tests, all of the athletes completed the health survey used to determine their health status and a form to state that they had participated in the research voluntarily. Each participant was told the content of the story in details. They were warned not to do heavy exercise or drink alcohol the before measurements were made. For each participant, the following measurements were made respectively: 1 ) Height and weight measurement, 2) 5-minute warm up run, 3) trial measurements so that participants could adjust to the balance platform, 4)static balance measurements, 5) jumping measurements; and then the procedure was ended. The research was conducted in the physiology laboratory of the School of Physical Education and Sport of Ağrı Ibrahim Çeçen University.

\section{Height and Weight Measurements}

A height measurement instrument (SECA, Germany) with measurement precision of $0.01 \mathrm{~mm}$ was used to measure the participants' height whereas a scale (SECA, Germany) with measurement precision of $0.1 \mathrm{~kg}$ was used to measure their weight (16).

\section{Body Mass Index (BMI)}

BMI was calculated by dividing the weight in $\mathrm{kg}$ into the square of height measurement in metres $\left(\mathrm{kg} / \mathrm{m}^{2}\right)(22,24,28)$.

\section{Static Balance Measurements}

Static balance measurement was performed (with Pro-kin, Technology, Dalmine, Italy, $20 \mathrm{~Hz}$ sampling rate, sensitivity $0.1^{\circ}$, product type: PK 252), by selecting static stability assessment module. Having described the data to the participants, the data were put to computer (as height, weight, age), and then the equipment was calibrated. The participants put their naked feet on the balance platform by paying attention to the lines on the $x$ and $y$ axes. The test was started by pressing the start button on the computer's keyboard, and it was finished automatically by the computer at the end of the test. Static balance test was performed standing on two legs with eyes open. The participants were asked to leave their hands free on sides (1). Static balance values were recorded as center of pressure in the $x$-axis (ACOPX), center of pressure in the $y$ axis (ACOPY) (25), forward-backward standard deviation (FBSD), medium lateral standard deviation (MLSD), average forward-backward speed (AFBS), average medium-lateral speed (AMLS), Perimeter (P) (mm), Elips area (EA) $\left(\mathrm{mm}^{2}\right)$ $(4,8,9,14,15,17,30,31)$.

\section{Jumping Tests}

How high the athletes jumped was measured with the methods of static jump, counter movement jump, and drop jump. Powertimer PC 1.9.5 Version New test equipment, the "mat" connected to the equipment and a computer programme were used in measurements. All athletes did jumping tests three times each. The averages found for the jump values, and then they were recorded. Jump values were recorded as jumping height $(\mathrm{JH})(\mathrm{cm})$, and jumping power (JP) (watts).

Static jump (SJ): The athletes jumped as high as they could on the "mat" on two feet with hands on the waist with $90^{\circ}$ squat.

Counter movement jump (CMJ): The athletes jumped as high as they could on the "mat" on two feet with hands on the waist with $90^{\circ}$ squat by coming down quickly.

Drop jump (DJ): The athletes fell on the mat from the step of $40 \mathrm{~cm}$ high with hands on the waist, and as 
soon as their feet contacted the ground, they jumped upward in half squat as high as they could (5).

\section{Statistical Analysis}

Statistical analyses were done by using the SPSS 22.0 programme. The "Descriptive" test was employed for numerical variables, and descriptive statistics were represented as averages \pm standard deviations. Because parametric test assumptions were not met in analysing the independent variables for the participants, Spearman's Moments Multiplication Correlation test was used. The results were evaluated in $95 \%$ reliability interval and the value of $p<0.05$ was regarded significant.

\section{RESULTS}

Table 1 shows the participants' age, height, weight, BMI and the age of sport. The athletes were $21.96 \pm 2.24$ years old, $178 \pm 7.11 \mathrm{~cm}$ tall, $69.64 \pm 8.56 \mathrm{~kg}$ heavy, and their BMI was $21.95 \pm 2.33\left(\mathrm{~kg} / \mathrm{m}^{2}\right)$, and their age of sport was $6.96 \pm 3.50$ years old.

An examination of the static balance test averages shown in Table 2 makes it clear that handball players had the best performance which was followed by soccer players, and that the lowest performance was in volleyball players. On examining the averages for jumping test SJ, CMJ, DJ scores, it was found that volleyball players had the best performance, followed by soccer players, and that handball players had the lowest performance.

According to Table 3, statistically significant correlations were not found between jumping in different methods SJ, CMJ (cm) and static balance parameters in consequence of Spearman's correlation statistic ( $p>0.05)$. Yet, it may be said that there are significant correlations between DJ $(\mathrm{cm})$ and balance parameters $(\mathrm{p}<0.05)$.

Table 1. The physical properties of the participants included in the research.

\begin{tabular}{lcccccc}
\hline & $\mathrm{N}$ & Age (years) & Height $(\mathrm{cm})$ & Body weight $(\mathrm{kg})$ & BMI $(\mathrm{kg} / \mathrm{m} 2)$ & Age of Sport (years) \\
\hline Handball & 14 & $22.57 \pm 1.65$ & $180.43 \pm 7.04$ & $74.43 \pm 7.56$ & $22.87 \pm 1.98$ & $6.86 \pm 3.61$ \\
Volleyball & 13 & $22.15 \pm 3.18$ & $180.46 \pm 8.34$ & $68.41 \pm 7.28$ & $21.12 \pm 2.82$ & $6.77 \pm 3.32$ \\
Soccer & 19 & $21.37 \pm 1.77$ & $174.79 \pm 4.95$ & $66.95 \pm 8.93$ & $21.84 \mathrm{~V} 2.07$ & $7.16 \pm 3.72$ \\
Total & 46 & $21.96 \pm 2.24$ & $178.11 \pm 7.11$ & $69.64 \pm 8.56$ & $21.95 \pm 2.33$ & $6.96 \pm 3.50$ \\
\hline
\end{tabular}

Table 2. Descriptive statistics for the participating athletes' balance and jumping scores.

\begin{tabular}{|c|c|c|c|c|c|c|c|c|c|}
\hline & & \multicolumn{2}{|c|}{ Handball } & \multicolumn{2}{|c|}{ Volleyball } & \multicolumn{2}{|c|}{ Soccer } & \multicolumn{2}{|c|}{ Total } \\
\hline & & Mean & SD & Mean & SD & Mean & SD & Mean & SD \\
\hline \multicolumn{10}{|c|}{ Double Feet Static Balance } \\
\hline \multicolumn{2}{|c|}{ ACOPX } & 1.14 & 1.29 & 0.92 & 0.95 & 0.74 & 1.19 & 0.91 & 1.15 \\
\hline \multicolumn{2}{|c|}{ ACOPY } & 0.57 & 0.65 & 0.77 & 0.44 & 1.11 & 1.41 & 0.85 & 1.01 \\
\hline \multicolumn{2}{|l|}{ FBSD } & 2.50 & 0.85 & 4.15 & 2.30 & 3.89 & 3.60 & 3.54 & 2.71 \\
\hline \multicolumn{2}{|c|}{ MLSD } & 1.50 & 0.85 & 1.92 & 0.95 & 1.95 & 1.61 & 1.80 & 1.24 \\
\hline \multicolumn{2}{|c|}{$\operatorname{AFBS}(\mathrm{mm} / \mathrm{s})$} & 6.71 & 1.90 & 10.62 & 3.78 & 10.16 & 4.73 & 9.24 & 4.08 \\
\hline \multicolumn{2}{|c|}{ AMLS (mm/s) } & 5.21 & 2.26 & 7.31 & 3.54 & 6.11 & 2.56 & 6.17 & 2.85 \\
\hline \multicolumn{2}{|c|}{$\mathrm{P}(\mathrm{mm})$} & 240.07 & 70.81 & 361.46 & 137.26 & 313.63 & 135.59 & 304.76 & 126.85 \\
\hline \multicolumn{2}{|c|}{$\mathrm{EA}\left(\mathrm{mm}^{\wedge} 2\right)$} & 73.79 & 91.79 & 159.92 & 124.85 & 170.63 & 247.00 & 138.13 & 181.29 \\
\hline \multicolumn{10}{|c|}{ Vertical Jumping Test } \\
\hline \multirow[t]{2}{*}{ SJ } & $\mathrm{JH}(\mathrm{cm})$ & 36.46 & 5.82 & 41.78 & 9.56 & 36.84 & 4.84 & 38.12 & 6.99 \\
\hline & $\mathrm{JP}$ (watt) & 3531.07 & 338.29 & 3536.69 & 638.79 & 3476.79 & 1005.13 & 3510.24 & 739.46 \\
\hline \multirow[t]{2}{*}{ CMJ } & $\mathrm{JH}(\mathrm{cm})$ & 37.86 & 5.89 & 48.12 & 10.17 & 38.42 & 5.74 & 40.99 & 8.45 \\
\hline & $\mathrm{JP}$ (watt) & 3614.79 & 387.67 & 3922.62 & 710.41 & 3561.95 & 978.97 & 3679.96 & 765.22 \\
\hline \multirow[t]{2}{*}{ DJ } & $\mathrm{JH}(\mathrm{cm})$ & 39.86 & 6.04 & 45.21 & 5.99 & 39.94 & 5.67 & 41.20 & 6.28 \\
\hline & JP (watt) & 2280.07 & 377.13 & 2468.15 & 620.32 & 2039.11 & 604.59 & 2233.70 & 567.85 \\
\hline
\end{tabular}


Table 3. Spearman's rank differences correlation analysis results for the correlations between athletes' jumping test values and scores for double feet static balance.

\begin{tabular}{|c|c|c|c|c|c|c|c|c|c|}
\hline \multirow{2}{*}{ Vert. Jumping Tests } & \multicolumn{9}{|c|}{ Double Feet Static Balance } \\
\hline & & ACOPX & ACOPY & FBSD & MLSD & $\begin{array}{c}\text { AFBS } \\
(\mathrm{mm} / \mathrm{s})\end{array}$ & $\begin{array}{l}\text { AMLS } \\
(\mathrm{mm} / \mathrm{s})\end{array}$ & $\begin{array}{c}\mathrm{P} \\
(\mathrm{mm})\end{array}$ & $\begin{array}{c}\text { E.A } \\
\left(\mathrm{mm}^{\wedge} 2\right)\end{array}$ \\
\hline \multicolumn{10}{|l|}{ SJ } \\
\hline \multirow{2}{*}{$\mathrm{JH}(\mathrm{cm})$} & $\mathrm{r}$ & 0.029 & 0.158 & 0.076 & -0.029 & 0.232 & 0.135 & 0.271 & 0.085 \\
\hline & $\mathrm{p}$ & 0.850 & 0.294 & 0.616 & 0.848 & 0.121 & 0.371 & 0.069 & 0.574 \\
\hline \multirow{2}{*}{ JP (watt) } & $\mathrm{r}$ & $.425\left(^{* *}\right)$ & -0.001 & -0.231 & -0.058 & -0.091 & 0.063 & -0.022 & -0.085 \\
\hline & $\mathrm{p}$ & 0.003 & 0.996 & 0.123 & 0.702 & 0.548 & 0.678 & 0.882 & 0.575 \\
\hline \multicolumn{10}{|l|}{$C M J$} \\
\hline \multirow{2}{*}{$\mathrm{JH}(\mathrm{cm})$} & $\mathrm{r}$ & 0.088 & 0.183 & 0.217 & 0.046 & 0.235 & 0.181 & $.322\left(^{*}\right)$ & 0.161 \\
\hline & $\mathrm{p}$ & 0.559 & 0.223 & 0.147 & 0.763 & 0.115 & 0.228 & 0.029 & 0.286 \\
\hline \multirow{2}{*}{ JP (watt) } & $\mathrm{r}$ & 0.164 & 0.209 & -0.022 & 0.034 & -0.011 & 0.068 & 0.095 & -0.013 \\
\hline & $\mathrm{p}$ & 0.275 & 0.164 & 0.883 & 0.824 & 0.941 & 0.653 & 0.532 & 0.934 \\
\hline \multicolumn{10}{|l|}{ DJ } \\
\hline \multirow{2}{*}{$\mathrm{JH}(\mathrm{cm})$} & $\mathrm{r}$ & $.323\left(^{*}\right)$ & 0.260 & $\left..4433^{(* *}\right)$ & 0.266 & 0.253 & $.318\left(^{*}\right)$ & $.338\left(^{*}\right)$ & $.369\left(^{*}\right)$ \\
\hline & $\mathrm{p}$ & 0.028 & 0.081 & 0.002 & 0.074 & 0.089 & 0.031 & 0.022 & 0.012 \\
\hline \multirow{2}{*}{ JP (watt) } & $\mathrm{r}$ & 0.261 & $.298\left(^{*}\right)$ & 0.163 & 0.105 & 0.083 & 0.105 & 0.123 & 0.099 \\
\hline & $\mathrm{p}$ & 0.079 & 0.044 & 0.278 & 0.489 & 0.585 & 0.486 & 0.415 & 0.513 \\
\hline
\end{tabular}

${ }^{*} \mathrm{p}<0.05,{ }^{* *} \mathrm{p}<0.01$

\section{DISCUSSION}

There are studies in the literature demonstrating the effects of balance and proprioceptive activities on bio motor properties. While some of them show significant the effects of balance activities on performance, some others suggest that those activities reduce the development of performance $(3,10,27,33)$.

This study did not find any statistically significant correlations between SJ and CMJ $(\mathrm{cm})$ two methods of jumping- and static balance parameters. However, it may be said that there are significant correlations between DS $(\mathrm{cm})$ and static balance parameters.

Hamilton et al. (11) analysed the correlations between balance and triple jump distance, and between vertical jump and balance performance. It was reported in consequence that there were no correlations between soccer players' balance performance, triple jump, and vertical jump distances. These findings are in parallel to the ones obtained in our study because no correlations were found between SJ, CMJ and static balance. Moreover, because correlations were found in our study between DJ and static balance, the findings obtained in the above mentioned research are supportive of our findings.

Miyaguchi \& Demura (21) analysed the factors determining the foot of jumping during jump movements, and called attention to balance and isotonic force as the important determiners of dominance, and to the fact that such a determination at lower extremes might not yield the same results at the higher extremes. Tweter \& Holm (29) found increases in jump distance and in quadriceps power in their research with 7-12 year olds, but they only found a small fluctuation in their static balance. The findings obtained are partly supportive of our findings.

Simek et al. (27) researched the effects of proprioceptive training programmes involving one leg and double leg static and dynamic balance activities on jump and agility. While the study group $(n=37)$ did proprioceptive training 3 times a week for 10 weeks, the control group $(n=38)$ continued their daily activities. The researchers found based on the test results that proprioceptive activities improved jump and agility- which are indicators of leg power. Granacher et al. (10) looked postural swinging on the balance platform and at jump height on the strength platform in consequence of four-week balance activities integrated into physical education classes in their research with adolescents; they also measured maximal isometric leg EKS power as pre-test and post-test on leg-press, and thus they exhibited that balance activities developed postural control significantly, increased jump height, and also improved the development of leg extensor muscles' power. Myer et al. (23) selected 19 female university athletes. They did not expose 8 of them who were 
doing plyometric exercise to any dynamic balance exercise, but remaining 11 athletes who were in the balance activities group were exposed to maximum level jumps. During the seven-week training which was offered three times a week, the effects of plyometric training programme, dynamic stabilisation and balance training programmes on sport performance markers such as vertical jump and power were compared. Following the training programme, it was observed that there was progress in mediolateral stability, in vertical jump height, isokinetic hamstring peak torch, in hamstringquadriceps power rates, in estimated $1 \mathrm{RM}$ bench presses, in hang clean and parallel squat performances.

Simek et al. (27), Granacher et al. (10) and Myer et al. (23) all found that balance training increased jump height and that jump training improved balance performance. Therefore, it may be thought that there are correlations between jump and balance. The results of the studies conducted on the basis of this belief support our results.

As a result, it was found that there were statistically significant correlations between static balance and drop jump in athletes. But that there were no significant correlations between static jump and counter movement jump. It is recommended that more drop jump exercise should be allocated in athletes' training programmes for the development of static balance performance and for the reduction of sports injuries.

\section{REFERENCES}

1. Cattaneo D, Jonsdottir J. Sensory impairments in quiet standing in subjects with multiple sclerosis. Multiple Sclerosis, 2009; 15(1): 59-67.

2. Chaouachi A, Othman AB, Hammami R, Drinkwater EJ, Behm DG. The combination of plyometric and balance training improves sprint and shuttle run performances more often than plyometric-only training with children. J Strength Cond Res, 2014; 28(2): 401-412.

3. Cressey EM, West CA, Tiberio DP, Kraemer WJ, Maresh CM. The effects of ten weeks of lower-body unstable surface training on markers of athletic performance. J Strength Cond Res, 207; 21(2): 561-567.

4. Cankaya S, Gokmen B, Tasmektepligil MY, Con M. Special Balance Developer Training Applications on Young Males' Static and Dynamic Balance Performance. Anthropologist, 2015; 19(1): 31-39.

5. Çon M, Akyol P, Tural E, Taşmektepligil MY. The effect of flexibility and body fat percentage on vertical jump performance with volleyball players. Selçuk University Journal of Physical Education and Sport Sciences, 2012; 14(2): 202-204.
6. Dündar U. Antreman Teorisi. Ankara: Nobel Yayınları, 2007, $49-66,123-78$

7. Fatouros IG, Jamurtas AZ, Leontsini D, Taxildaris $K$, Aggelousis N, Kostopoulos N, Buckenmeyer P. Evaluation of plyometric exercise training, weight training, and their combination on vertical jumping performance and leg strength. The Journal of Strength \& Conditioning Research, 2000; 14(4): 470-476

8. Göktepe M, Şenel Ö, Özkan A. Bazı Raket Sporlarıyla Uğraşan Sporcuların Reaksiyon Zamanları Ve El Kavrama Kuvvetleri İle Denge Ve Proprioseptif Duyularının İlişkisi. SSTB International Refereed Academic Journal of Sports, Health \& Medical Sciences, 2015; 17.

9. Güngör G. Gemi Zabitleri - Zabit Adayları İle Kürek Sporcularının Karşılaştırmalı Denge Analizleri, İstanbul Teknik Üniversitesi Fen Bilimleri Enstitüsü Deniz Ulaştırma Anabilim Dalı, Yüksek Lisans Tezi, İstanbul, 2010.

10. Granacher U, Gollhofer A, Kriemler S. Effects of balance training on postural sway, leg extensor strength, and jumping height in adolescents. Research Quarterly for Exercise and Sport, 2010; 81(3): 245-251.

11. Hamilton RT, Shultz SJ, Schmitz RJ, Perrin DH. Triple-hop distance as a valid predictor of lower limb strength and power. Journal of Athletic Training, 2008; 43(2): 144-151.

12. Horak FB. Clinical measurement of postural control in adults. Physical Therapy, 1987; 67(12): 1881-1885.

13. Kahramanoğlu Ç. Halter ve pliometrik çalışmaların hızlanmaya etkisi. İstanbul, Marmara Üniversitesi Sağlık Bilimleri Enstitüsü, Beden Eğitimi ve Spor Anabilim Dalı, Yüksek Lisans Tezi, 2006

14. Karadenizli ZI, Erkut O, Ramazanoglu N, Uzun S, Camliguney AF, Bozkurt S, Sirmen B. Comparision of dynamic and static balance in adolescents handball and soccer players. Turkish Journal of Sport and Exercise, 2014; 16(1): $47-54$

15. Karakaş F. Çoklu reaksiyon zamanı ile izokinetik denge arasındaki ilişkinin incelenmesi. Ondokuz Mayıs Üniversitesi Sağlık Bilimleri Enstitüsü Beden Eğitimi Ve Spor Anabilim Dalı, Yüksek Lisans Tezi, Samsun, 2012.

16. Köklü Y, Özkan A, Alemdaroğlu U, Ersöz G. Genç futbolcuların bazı fiziksel uygunluk ve somatotip özelliklerinin oynadıkları mevkilere göre karşılaştırılması. Spormetre Beden Eğitimi ve Spor Bilimleri Dergisi, 2009; VII(2): 61-68.

17. Köse B. Farklı ısınma yöntemlerinin esnekliğe sıçramaya ve dengeye etkisi. Ondokuz Mayıs Üniversitesi Sağlık Bilimleri Enstitüsü Beden Eğitimi ve Spor Anabilim Dalı, Yüksek Lisans Tezi, Samsun, 2014.

18. Laskowski ER, Newcomer-Aney K, Smith J. Refining rehabilitation with proprioception training: expediting return to play. The physician and sportsmedicine, 1997; 25(10): 89102.

19. Lloyd RS, Meyers RW, Oliver JL. The natural development and trainability of plyometric ability during childhood. Strength \& Conditioning Journal, 2011; 33(2): 23-32.

20. Luebbers PE, Potteiger JA, Hulver MW, Thyfault JP, Carper MJ, Lockwood RH. Effects of plyometric training and recovery on vertical jump performance and anaerobic power. 
The Journal of Strength \& Conditioning Research, 2003; 17(4): 704-709.

21. Miyaguchi K, Demura S. Specific factors that influence deciding the takeoff leg during jumping movements. The Journal of Strength \& Conditioning Research, 2010; 24(9): 2516-2522.

22. Moran GT, McGlynn G. Dynamics of Training and Conditioning. Second Edition. USA: WBC/McGraw-Hill, 1997.

23. Myer GD, Ford KR, Brent JL, Hewett TE. The effects of plyometric vs. dynamic stabilization and balance training on power, balance, and landing force in female athletes. The Journal of Strength \& Conditioning Research, 2006; 20(2): 345353.

24. Norris JM, Langefeld CD, Scherzinger AL, Rich SS, Bookman E, Beck SR, Saad MF, Haffner SM, Bergman RN, Bowden DW, Wagenknecht LE. Quantitative trait loci for abdominal fat and BMI in hispanic-americans and African-Americans: The IRAS family study, International Journal of Obesity, 2005; 29: 67-77.

25. Prosperini L, Fortuna D, Giannì $C$, et al. The diagnostic accuracy of static posturography in predicting accidental falls in people with multiple sclerosis, Neurorehabilitation and Neural Repair, 2013; 27: 45-52.

26. Robinson LE, Devor ST, Merrick MA, Buckworth J. The effects of land vs. aquatic plyometrics on power, torque, velocity, and muscle soreness in women. The Journal of Strength \& Conditioning Research, 2004; 18(1): 84-91.

27. Šimek S, Milanović D, Jukić I. The effects of proprioceptive training on jumping and agility performance. Kineziologija, 2008; 39(2): 131-141.

28. Taylor RW, Keil D, Gold EJ, Williams SM, Goulding A. Body mass index, waist girth and waist-to-hip ratio as indexes of total and regional adiposity in woman: Evalution using receiver operating characteristics curves, The American Journal of Clinical Nutrition, 1998; 67: 44-49.

29. Tweter AT, Holme I. Influence of Thigh Muscle Strength And Balance on Hop Length in One Legged Hopping in Children Aged 7-12 years, Gait \& Posture, 2010; 32(2): 259-262.

30. Url 1. http://www.tecnobody.it (last access date: 10 January 2016).

31. Wang S, Yang J, Zhu Y. Reliability and validity of static balance measures in hemiplegic patients using balance feedback training equipment. Chinese Journal of Rehabilitation Medicine, 2011; 11: 013.

32. Winter DA, Patla AE, Frank JS. Assessment of balance control in humans. Med Prog Technol, 1990; 16(1-2): 31-51.

33. Witmer CA, Oberacker LM, Moir GL, Davis SE, Haff GG. The effects of stable and unstable surface resistance training on performance of female soccer players. Medicine and Science in Sports and Exercise, 2011; 43: S583. 